\title{
Türkçede İşitsel Deneylerde Kullanılan Çapraz Birleştirmeli Uyaran Yönteminin Sınanması*
}

\author{
İpek Pınar Bekâr \\ Ankara Üniversitesi, Dil ve Tarih-Coğrafya Fakültesi, Dilbilim Bölümü, 06100 \\ Sihhiye/Ankara \\ pinarbekar@gmail.com
}

(Gönderilme tarihi 14 Mart 2017; kabul edilme tarihi 21 Haziran 2017)

\begin{abstract}
ÖZ: Dil sisteminin beyinde zamansal açıdan nasıl işlemlendiğinin açıklanabilmesi için beyin araştırmalarının ve dilbilimin verilerinin birlikte yorumlanması gerekmektedir. İşitsel teknik kullanılarak elde edilen işitsel uyaranların bu bağlamda incelenmesiyle, dilin beyindeki sesbilimsel işlemlenişi daha açık biçimde ortaya konulabilmektedir. Bu araştırmada, Bekâr (2016)'da EEG tekniği aracılığıyla incelenen işitsel uyaranların akustik önişlemleme süreci üzerinde durulmaktadır. $\mathrm{Bu}$ önişlemleme süreci araştırmada, Çapraz Birleştirmeli Uyaran (Stimulus Cross-Splicing) yöntemi olarak tanımlanmaktadır. PRAAT 5.2 Ses Çözümleme Programında uygulanan bu yöntem aracılığıyla oluşturulan işitsel uyaranlar, aynı araştırma sorularıyla kurulan ancak akustik önişlemleme sürecinden geçirilmemiş olan bir başka EEG deneyinin işitsel uyaranlarıyla, temel sıklık (F0) ve sesletim süreleri çerçevesinde karşılaştırılmalı yorumlanmaktadır. Temel sıklık (F0) ve sesletim süreleri kullanılarak, ses çaprazlama işleminin gerçekleştirileceği işitsel uyaranların sıfır geçiş noktaları (0-) belirlenmekte ve ses kayıtları doğallığını kaybetmemektedir. Türkçe açısından özgün olan bu yöntem, Türkçenin parçalı ve parçalarüstü sesbilimsel bileşeninin incelendiği beyin araştırmalarında uygulanan işitsel uyaranların daha güvenilir bulgular sunabilmesini sağlamaktadır. İşitsel uyaranların istatistiksel yöntemlerle karşılaştırıldığı bu araştırmanın bulguları, akustik önişlemleme sürecinin Türkçede önemini ortaya koymaktadır. Buna göre, akustik önişlemleme
\end{abstract}

Bu yazı, Türkiye Bilimsel ve Teknolojik Araştırma Kurumu (TÜBİTAK) 1001Bilimsel ve Teknolojik Araştırma Projelerini Destekleme Programı'na ait 112K394 No'lu "Türkçe Sözlü Dildeki Fonolojik Anlamlandırma Süreçlerinin Beyindeki İşlemlenişi ve Lokalizasyonu: Bir Elektrofizyolojik İnceleme" adlı proje çerçevesinde desteklenmektedir. Yazıya ait verilerin oluşturulması aşamasında, söz konusu projenin bir parçasını oluşturan ve İpek Pınar Bekâr'a ait "Türkçede Eylem-Sonu Konumunda Bürün-Sözdizim Etkileşimi Üzerine Elektrofizyolojik Bir İnceleme" başlıklı doktora tezinden yararlanılmıştır.

Yazının hazırlanması sürecindeki desteklerinden ve yapıcı eleştirilerinden ötürü Prof. Dr. İclâl Ergenç'e, Prof. Dr. Özgür Aydın'a ve Prof. Dr. Canan Kalaycıŏglu'na teşekkür ederim. 
kullanılarak, aynı dilbilimsel sorunu inceleyen iki ayrı beyin görüntüleme çalışmasında bu yöntemin deney sonuçlarına nasıl etki ettiği ve ileri araştırmalardaki gerekliliği vurgulanmaktadır.

Anahtar Sözcükler: çapraz birleştirmeli uyaran, temel sıklık, sesletim süresi, işitsel uyaran, EEG

\section{Examining the Stimulus Cross-Splicing Method on Auditory Experiments in Turkish}

ABSTRACT: To explain how the language system in the brain is temporally processed, the results of both brain and linguistics researches are required to be interpreted together. In this regard, phonologic functioning of language in the brain may be demonstrated more clearly by examining the auditory stimuli which are obtained via using auditory technique. This study focuses on acoustic preprocessing of auditory stimuli by using EEG technique in Bekâr (2016). This preprocessing is described as Stimulus Cross-Splicing method in this study. The auditory stimuli which was prepared in PRAAT 5.2 Sound Analysis Program with this method are interpreted contrastively by means of duration and fundamental frequency (F0) with an auditory stimuli of another EEG experiment, which has the same research questions without an acoustic preprocessing. Zero-crossing (0-) of the auditory stimuli are determined by using fundamental frequency and duration and the recordings keep their naturality. This preliminary method on Turkish provides more reliable results with the use of auditory stimuli that was built on brain studies in which the segmental and suprasegmental phonologic components in Turkish are investigated. Findings of this study reveals the importance of acoustic preprocessing in Turkish by examining the auditory stimuli with statistical methods. According to these findings, the way this method affects the results of the experiment and the necessity of using an acoustic preprocessing in two different brain imaging researches which try to answer the same linguistic issues are emphasized for future studies.

Keywords: cross-splicing, fundamental frequency, duration, auditory stimulus, EEG

\section{Giriş}

İnsan beyninin temel araştırma nesnelerinden biri olan dilin beyinde nasıl işlemlendiğinin ortaya konulabilmesi için hem beyin araştırmalarının hem de dilbilime ait verilerin ortak yöntemlerle incelenmesi gerekmektedir. Dilin zamansal (temporal) açıdan araştırıldığ 1 bu tür çalışmalarda işitsel teknik (auditory technique) kullanılarak üretilen işitsel uyaranlar (auditory stimuli) aracılığıyla, dilin parçalı ve parçalarüstü sesbirimlerinin temel işleyişleri ve bu sesbirimlerin dilin diğer bileşenleriyle olan etkileșimi ortaya konulabilmektedir. $\mathrm{Bu}$ bağlamda, olaya ilişkin potansiyeller (OİP) (event-related potentials), 
wavelet (salınım) gibi yöntemlerle beyin dalgalarının aktivitesini ölçen Elektroensefalografi (EEG) (Electroencephalography) tekniği kullanılarak, Friederici (2002)'de sunulan İşitsel Tümce İşlemleme (Auditory Sentence Processing) sürecini inceleyen disiplinlerarası nitelikli pek çok araştırma bulunmaktadır. Bu araştırmalar sözlü dilin üretim, algılama ve anlamlandırma aşamalarında beynin hangi bölgelerinde zamansal bir etkileşimin oluştuğunu incelemektedir. İşitsel Tümce İşlemleme sürecinde kullanılan işitsel uyaranlar aracılığıyla, sözlü dilin kurucu ve yorumlayıcı bileşenlerinin OİP yöntemiyle beyinde nasıl işlemlendiğini ortaya konabilmektedir.

Almancada bürünsel bozulma gösteren yapılarda farklı işitsel uyaranlar ve araştırma sorularıyla bürün-sözdizim etkileşimini inceleyen Eckstein ve Friederici (2005) ile Eckstein ve Friederici (2006)'da Să̆ Ön Negativite (Right Anterior Negativity/RAN) Etkisi ve $\mathrm{P} 600^{2}$ (Positive 600) gibi OİP değerlerine ulaşılmıştır. Patel ve diğerleri (1998), Koelsch ve diğerleri (2000), Koelsch ve diğerleri (2005) ve Koelsch (2009) gibi araştırmalarda ise, işitsel uyaranlar kullanılarak müzikteki harmoni ve sözdizim arasında etkileşim incelenmiş ve Erken Să̆ Ön Negativite ${ }^{3}$ (Early Right Anterior Negativity/ERAN) Etkisi ve P600 potansiyelleri elde edilmiştir. Fransızcada bürün ve anlam arakesitini inceleyen Astésano, Besson ve Alter (2004) ile Magne ve diğerleri (2007)'de ise P800 ${ }^{4}$ (Positive 800) potansiyeline ulaşılmıştır. Alanyazında ilk defa Steinhauer, Friederici ve Alter (1999)'da

\footnotetext{
${ }^{1}$ Eckstein ve Friederici (2005)'te işitsel olarak tümcenin anlamlandırılması sürecinde ortaya çıktığı ileri sürülen Sağ Ön Negativite (RAN) Etkisi, bürünsel açıdan bozulma gösteren yapılarda uyaran sunumundan sonra 400-600 ms aralığında tepe noktasına ulaşmaktadır. Bürünsel bozulmanın temel etkisini gösteren ve beynin sağ yarıküresinde ön alanda görülen bu etki, öbek-sonu ya da tümce-sonu konumlarında gözlenmektedir.

2 Osterhout ve Holcomb (1992)'de Sözdizimsel Pozitif Sapma olarak tanımlanan, ardından Hagoort, Brown ve Groothusen (1993)'te P600 biçiminde yeniden adlandırılan P600 potansiyeli, uyaran sunumundan sonra $600 . \mathrm{ms}$ 'de pozitif yönde polarite yapan geniş yayılımlı bir potansiyeldir. Beynin orta-parietal ve arka alanlarında gözlemlenen P600, hem sözdizimsel hem de bürünsel yapılarda dilbilimsel bir bozukluğu genellikle düzeltme, çözümleme ya da telafi etme süreci olarak tanımlanmaktadır.

3 Koelsch ve diğerleri (2000)'de ritme dayalı müzikal uyum taşıyan yapılardaki bozulmalarda gözlemlendiği ileri sürülen Erken Sağ Ön Negativite (ERAN) Etkisi, uyaran sunumundan sonra 200.ms'de RAN Etkisi'ne benzer bir topografik alanda tepe noktasına ulaşmaktadır.

${ }^{4}$ Geç dönemli P600 olarak da bilinen P800 potansiyeli, Astésano, Besson ve Alter (2004)'te bürün ve anlam arakesitinde ortaya çıkmıştır. Bürünün anlamsal açıdan bozulduğu yapılarda temel etkisi gösteren ve uyaran sunumundan sonra yaklaşık 800$1100 \mathrm{~ms}$ aralığında tepe noktasına ulaşan bu potansiyel, P600'den farklı olarak geniş yayılım göstermemekte ve temporo-parietal alanda konumlanmaktadır.
} 
ortaya konulan ve işitsel teknik kullanılarak Almanca durakların bürünsel etkisinin incelendiği bir araştırmada Son Pozitif Sapma ${ }^{5}$ (Closure Positive Shift/CPS) etkisine ulaşılmıştır. Benzer etki, Steinhauer ve Friederici (2001), Pannekamp ve diğerleri (2005), Wolff ve diğerleri (2008), Kerkhofs ve diğerleri (2007), Li ve Yang (2009) ve Hwang ve Steinhauer (2011) gibi pek çok araştırmada farklı dillerde incelenmiştir. Türkçede ise bu araştırmanın da işitsel uyaran analizlerinin büyük bir kısmını oluşturan Bekâr (2016)'da, geçişli eylemlerden oluşan bildirim tümcelerinde eylem-sonu konumunda bürün-sözdizim etkileşiminde RAN Etkisi, P600 ve P800 gibi OİP değerleri elde edilmiştir.

$\mathrm{Bu}$ araştırmada yukarıda sözü edilen araştırma bulgularıyla ulaşılan betimlemeler çerçevesinde, EEG tekniği kullanılarak Türkçede eylem-sonu konumunda bürün-sözdizim etkileşimini inceleyen iki ayrı deneye ilişkin işitsel uyaran setleri, Akustik Sesbilgisi (Acoustic Phonetics) alanının verilerinden yararlanılarak süreç-içi (online) ve süreç-dışı (offline) olmak üzere karşılaştırılmalı olarak ortaya konulacaktır. Bu kapsamda, Tablo 1'de de sunulduğu gibi, toplam 300 tümceden oluşan işitsel EEG deney deseninde, eylem-sonu konumunda görülen bürünsel ve sözdizimsel temelli iki dilsel bozulma bulunmaktadir.

Tablo 1. Örnek işitsel uyaran deseni

\begin{tabular}{|c|c|c|c|c|c|}
\hline Deney Koşulları & \multicolumn{3}{|c|}{ Deney Tümceleri } & Bürün & Sözdizim \\
\hline Dilbilgisel Koşul & ‘Ayşe & bahçede yıkadı & halı-yı' & düzgün & düzgün \\
\hline $\begin{array}{c}\text { Bürün Bozulması } \\
\text { Koşulu }\end{array}$ & ‘Ayşe & bahçede yıkadı & HALI-YI' & bozuk & düzgün \\
\hline $\begin{array}{c}\text { Sözdizim Bozulması } \\
\text { Koşulu }\end{array}$ & 'Ayşe & bahçede yıkad & halı-ya' & düzgün & bozuk \\
\hline $\begin{array}{c}\text { Bürün-Sözdizim } \\
\text { Bozulması Koşulu }\end{array}$ & ‘Ayşe & bahçede yıkad & HALI-YA' & bozuk & bozuk \\
\hline
\end{tabular}

5 Steinhauer, Friederici ve Alter (1999)'da bürünsel sınırlardaki bozulmalarda bulgulanan Son Pozitif Sapma (CPS), ezgi öbeklerinin kesiştiği noktalara göre belirlenmektedir. Diğer potansiyellerden farklı olarak bu etki için belirlenen zaman aralıkları, araştırmaların deney desenlerine göre değişim göstermekte ve CPS etkileri ezgi öbeklerinin kesiştiği alanların öncesi ve sonrası alınarak incelenmektedir. Pek çok dilde araştırılan CPS'nin (Ayrıntılı bilgi için bkz. Pannekamp ve diğerleri, 2005; Bögels, 2007; Männel ve Friederici, 2009; Hwang ve Steinhauer, 2011 gibi) genellikle beynin sol yarıküresinde ve arka alanlarında ortaya çıktığı görülmektedir. 
Tablo 1'deki ilk koşul (Dilbilgisel Koşul), hem bürünsel hem de sözdizimsel olarak düzgün tümceleri içermektedir. Bürünsel bozulmayı gösteren ikinci koşulu (Bürün Bozulması Koşulu), Türkçede eylem-sonu konumu odak içermeyen konum olarak kabul edildiği için (Erguvanl1, 1984; Göksel, 1998 gibi) eylem-sonunda yerinde olmayan odaklama ile oluşturulmuştur. Eylemsonu konumundaki AÖ’ler (Ad Öbeği) temel sıklık gibi akustik değerleri açısından eylem-öncesine göre çok daha düşük olduğu için Türkçede odaklı olarak kabul edilmemektedir. Durum eklerinin yerinde kullanılmamasiyla oluşturulan üçüncü koşulda (Sözdizim Bozulması Koşulu), kritik AÖ'nün aldığ1 sonekin belirtme durumdan yönelme durumuna dönüştürülmüştür. Bu durumda eylem yanlış durum eki ile eşleştirilmiştir. Hem bürünsel hem de sözdizimsel bozulmayı birlikte gösteren son koşulda ise (Bürün-Sözdizim Bozulması Koşulu), eylem-sonu konumunda bozuk odaklama ve yerinde olmayan durum eki kullanılarak ilgili deney tümcesi bozuk olarak sesletilmiştir.

Araştırmanın birinci bölümünde, Eckstein ve Friederici (2005), Eckstein ve Friederici (2006) ve Steinberg, Truckenbrodt ve Jacobsen (2012) gibi EEG tekniğini uygulayan pek çok araştırmanın işitsel uyaran setlerinin hazırlanması sürecinde kullanılmış olan Çapraz Birleştirmeli Uyaran (Stimulus Cross-Splicing) yöntemi Türkçeden örneklerle tanıtılmakta; ikinci bölümde ise bulgular, bu çözümleme yönteminin uygulanmadığı bir başka EEG deneyine ilişkin bulgularla karşılaştırılmaktadır. Bekâr (2016)'da Türkçede sınanan Çapraz Birleştirmeli Uyaran (ÇBU) yönteminin işitsel uyaranların sesletiminde oluşması beklenen olası akustik sorunları, doğal ses kaydını bozmadan büyük ölçüde en aza indirilebileceği ve ileride yapılması hedeflenen sesbilim temelli disiplinlerarası araştırmalarda uygulanmasının önemi de ortaya konulmaktadır. ÇBU yönteminin kullanıldı̆̆ araştırmalarında, katılımcıların yalnızca çözümlenecek dilsel alana odaklanmaları ve deneyin akışını bozacak diğer işlemlerden kaçınmaları da sağlanabilmekte, işitsel bulgulara ait bulanık olmayan güvenilir sonuçlara ulaşılabilmektedir.

$\mathrm{Bu}$ tür araştırmaların konusunu oluşturan işitsel uyaranların ve EEG deneylerinde kullanılması hedeflenen deney setlerinin ön hazırlık sürecinde sesbilimsel ve istatistiksel olarak deneye uygunluğunun sınanabilmesi için Akustik Sesbilgisi alanının verilerinden yararlanılması gerekmektedir. $\mathrm{Bu}$ bağlamda, araştırmanın ilk bölümünde akustik önişlemleme (preprocessing) sürecinde incelenmesi gereken temel sıklık (F0), harmonikler ve süre gibi temel akustik parametrelerden söz edilecektir. Bunun ardından, ÇBU yöntemi Bekâr (2016)'dan alınan veriler doğrultusunda açıklanacak ve yöntemsel açıdan betimlenecek olan EEG deneylerinin akustik değiştirgenleri istatistiksel olarak karşılaştırılıp yorumlanacaktır. 


\section{Akustik Değiștirgenler: Temel Sıklık (F0) ve Sesletim Süresi}

Ses (sound), hava basıncındaki düzenli ya da düzensiz değişimlere dayalı olarak oluşan moleküllerin titreşmesine neden olan dalgaların fiziksel ortama yayılması sonucu ortaya çıkmaktadır. Bu bağlamda, birim zaman içindeki en düşük s1klık değeri olarak kabul edilen sesin temel siklık değeri (F0) (fundamental frequency), Kent ve Read (2002)'ye göre, farklı ses dalgalarından oluşan karmaşık titreşimleri gösteren ve konuşma tanımlamanın temel özelliklerinden biri olarak kabul edilen akustik bir değiştirgendir. Ses yolunun kalınlığı, şekli, biçimi ve büyüklüğü gibi pek çok alt değiştirgenden etkilenen temel sıklık değeri, konuşucunun yaşı, cinsiyeti gibi çeşitli ayırıcı özellikleri göstermektedir. Ses değerinin kalınlaşması ile temel sıklığın ölçü birimi olan Hertz (Hz) değeri arasındaki ters orantı sonucu, temel sıklık çocuklarda yaklaşık $270 \mathrm{~Hz}$, yetişkin kadınlarda $220 \mathrm{~Hz}$ ve yetişkin erkeklerde $120 \mathrm{~Hz}$ civarında değişim göstermektedir.

Temel sıklık değeri açısından dikkatle hesaplanması gereken ses uyaranı çaprazlama işleminin temelinde, sesin sıfir geçiş noktasının (zero-crossing) tam olarak belirlenmesi büyük önem taşımaktadır. Sıfır geçiş noktası, zamana dayall ses perdesi analizi algoritmasındaki (time-domain algorithm) temel özelliklerden biridir. Buna göre, sıfır geçişinin akustik değerler çerçevesinde düzgün bir biçimde işaretlenmesi ile ses sinyalleri bu noktadan geçebilmektedir. Başka bir deyişle, sıfır geçişi herhangi bir ses sinyalinin negatif yönden pozitif yöne ya da pozitif yönden negatif yöne doğru akustik geçișini belirleyen zamansal değerlerin toplamı olarak da kabul edilebilmektedir. Aşağıda Şekil 1'de sıfır geçiş noktasının temel sıklığın ilk oluşum sürecindeki kesişim noktası gösterilmektedir.



Şekil 1. Sıfır geçiş noktası

Şekil l'de de görüleceği gibi, konuşmanın temel sıklık değerinin belirlenebilmesi amacıyla kullanılan sıfır geçiş noktasının her bir sınır aşaması, temel sıklığı belirleyen harmonikleri (harmonics) göstermektedir. Crystal (1980)'de de belirtildiği gibi sesin harmoniği, sesin temel sıklık değeri dışında üretilen yan frekanslar olarak kabul edilmektedir. Sesin harmoniği ve temel sıklığı arasındaki ilişki, harmoniklerin temel seslere ait frekansların katlarını 
oluşturması durumudur. Konuşma sesleri arasında en yüksek genliğe, ancak en düşük sıklığa sahip olan temel sıklık değeri, aynı zamanda (1.) harmonik olarak da adlandırılabilmektedir. Buna göre, (2.) harmonik frekansı temel sıklığın iki katını oluşturmaktadır. Aşağıdaki Şekil 2'de de gösterildiği gibi, bu katların her bir geçiş noktası da, o seslerin sıfır noktalarını göstermektedir. Sesin harmonik değeri ne kadar yüksekse, kalitesi de o kadar yüksek olduğu için, ses uyaranı çaprazlama işlemi sırasında uygulayıcının sesin temel sıklık ve harmonik değerleri ile ilgili ayrıntılı akustik birikime sahip olması gerekmektedir (Ayrıntılı bilgi için bkz. Boersma, 1993; Crystal, 1980; Kent ve Read, 2002; Ladefoged, 2006; Stevens, 2000).



Şekil 2. Temel sıklık çerçevesinde sesin harmonikleri ve sıfır geçiş noktaları

Şekil 2'de gösterildiği gibi, temel sıklık değerinin katmanlarının artması ile harmoniklerin değeri de orantılı biçimde artma göstermektedir. $\mathrm{Bu}$ artma sırasında gerçekleşen basınçlı hava akımının ses tellerinin titreşmesine neden olması ve geniz boşluklarının titreşim geçmesi gibi kimi fizyolojik değişimler sonucu konuşma sesleri karmaşık bir biçime dönüşmektedir. Alanyazında ilk olarak Fant (1960)'da Konuşma Üretiminin Akustik Kuramı (Speech Production of Acoustic Theory) ve Kaynak-Süzgeç Modeli (Source-Filter Model) çerçevesinde söz edilen bu dönüşüm, ses tayfindaki (spectrum) tepe noktaları olarak formant (formant) biçiminde tanımlanmaktadır. Formantlar, farklı sesbilimsel işlevler taşıyan F1, F2, F3, F4 gibi alt harmoniklerin, başka bir deyişle tınlama sıklıklarının oluşumunu sağlamaktadır. Temel sıklık gibi Hz ile ölçülen bu değerler, harmoniklerin katmanlarına ve sıfır geçiş noktalarının artışına dayalı olarak F0-F1 aralığı dışında $1000 \mathrm{~Hz}$ aralıkla artma göstermektedir. Buna göre, F1 formant1 500-1000 Hz, F2 formant1 1000-2000 $\mathrm{Hz}$, F3 formant $2000-3000 \mathrm{~Hz}$ ve F4 formant $13000-4000 \mathrm{~Hz}$ aralığinda yer almaktadır. Bu değerler, F0 değerlerinde olduğu gibi cinsiyete ve yaşa bağlı olarak artma ya da azalma gösterebilmektedir. 
Clark, Yallop ve Fletcher (2007)'de uzunluk (length) ya da nicelikle (quantity) ilişkilendiren ve bu araştırmanın diğer akustik değiştirgeni olan sesletim süresi (phonation of duration) ya da süre (duration), sesin temel görünümünü ortaya koyan spektrografik örüntülerde yatay düzlemde genellikli milisaniye (ms) olarak gösterilmektedir. Sesletim süresi, Crystal (1969)'a göre temel sıklığın ve harmoniklerin belirlendiği ses perdesinin (pitch) tanımlanmasında büyük rol oynamaktadır. Buna göre süre, bir sesin uzunluğu, ses grubu, ifade ya da sessizliğe karşılık gelmektedir. Bu araştırma kapsamında sesletim süresi, İşitsel Uyaran Seti (1) ve İşitsel Uyaran Seti (2) olarak adlandırılan EEG deneylerinin işitsel uyaranları oluşturan AÖ'lerin toplam zaman aralıklarını karşılaştırmak amacıyla ele alınan akustik bir değiştirgen olarak kabul edilmektedir. Aşağıda Şekil 3'te İşitsel Uyaran Seti (2)'de kullanılan [Müdür okulda dağıttı sinavı] tümcesinin spektrografik örüntüsü sunulmaktadır. Buna göre, 0-5000 Hz aralığında bölütlenen dikey alan tümcenin temel siklık ve formant değerlerini sunarken, 0-1.603 ms aralığında sunulan yatay düzlem tümcenin sesletim süresini göstermektedir.

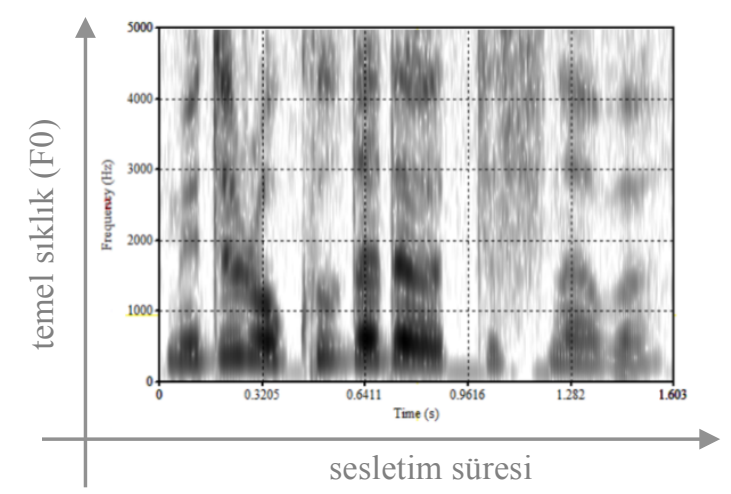

Şekil 3.Ttemel sıklık çerçevesinde sesin harmonikleri ve sıfır geçiş noktaları

\section{3 Çapraz Birleştirmeli Uyaran (ÇBU) Yöntemi}

Alanyazında dilin beyindeki sesbilimsel işlemlenişini EEG tekniği ile inceleyen Eckstein ve Friederici (2005), Eckstein ve Friederici (2006) ve Steinberg, Truckenbrodt ve Jacobsen (2012) gibi pek çok araştırmanın işitsel uyaran setlerinin oluşturulması sürecinde uygulanan ÇBU yöntemi Türkçede ilk defa Bekâr (2016)'da kullanılmıştır. Sesbilim alanyazınına yeni olmayan, ancak dilin sesbilimsel yönünü beyin görüntüleme teknikleriyle inceleyen araştırmalarda kullanılan işitsel uyaranların hazırlanmasında özgün olan bu teknik ile herhangi bir ses kaydının doğal örüntüsü bozulmadan deney koşulları arasında çaprazlama gerçekleştirilebilmektedir. Buna göre, aşağıda ayrıntılı olarak 
tanıtılacak bu teknik ile herhangi bir işitsel uyaranın temel sıklık değeri, harmonisi, sıfır geçiş noktası, ses kalitesi, genliği ve sesletim süresi gibi akustik değiştirgenlerinin belirlenmesi yoluyla, ses çaprazlama işlemi doğallığ bozmayacak biçime getirilebilmektedir. Katılımcılar beyin görüntüleme deneyleri sırasında farklı koşullara sahip, ancak odaklama alanları gibi aynı sesbilimsel örüntüleri taşıyan deney tümceleri arasında kritik sözcüğe kadar aynı söz öbeklerini duymaktadır. Böylelikle, işitsel uyaranların her seferinde farklı sesletilmesinden kaynaklanan sözcük uzunluğu (word length), oktav atlama (octave jump), şaklama (click) gibi akustik temelli doğal sesletim sorunları ortadan kalkmaktadır. Bu açıklama çerçevesinde, ÇBU yöntemi sırasında dikkate alınması gereken akustik ilkeler aşağıdaki basamaklar halinde sunulmaktadır:

i. Çaprazlanacak iki kaydın da sıfır geçiş noktaları belirlenmelidir.

ii. Sıfır geçiş noktaları belirlenen ses kayıtlarının genlik ve yoğunluk değerlerinin eş özellikli olması gerekmektedir. Örneğin, bir ses kaydı $60 \mathrm{~dB}$ değerindeyken, diğer kayıt $80 \mathrm{~dB}$ olmamalıdır. Bu durumda, ses yüksekliği farklılaşan ses kayıtları, aynı genlik ve yoğunluk değerlerini taşımadığı için çaprazlama işlemi sırasında sesin doğal özelliği bozulmaktadır.

iii. Ses perdesi, ses kalitesi, genlik, süre gibi değerler büyük oranda eş özellikte kaydedilmiş olmalıdır. Bu durumda, farklı bir laboratuvar ortamında kaydedilen ses kayıtlarının çaprazlama işlemi gerçekleştirilememektedir.

iv. Çaprazlama noktası belirlenmeli ve sıfır geçiş noktası genliğe dayalı olarak ayarlanmalıdır. Şaklama sesinin oluşması durumunda ses kaydının doğallığı ortadan kalkacağı için sıfır geçiş noktaları milisaniyelik değerlerle ayarlanmalıdır.

Bir önceki bölümde belirtildiği gibi, spektrogramların $(\mathrm{Hz})$ ile ölçülen dikey düzlemleri temel sıklık ve formant değerlerini, (ms) ile ölçülen yatay düzlemleri ise sesletim sürelerini göstermektedir. Bu araştırma kapsamında, spektrogramın bu temel iki akustik değiştirgenleri sesbilimsel ve istatistiksel çerçevede yorumlanmaktadır. Bu kapsamda, aşağıda Şekil 4'te Praat 5.2 Ses Çözümleme Programı (Boersma ve Weenink, 2010) kullanılarak gerçekleştirilen ÇBU örnekleri sunulmaktadır. Bekâr (2016)'dan alınan bu örneklerde, işitsel uyaran çaprazlama sırasında akustik çözümleme sesletim süresi (ms) ve temel sıklık (Hz) değerleri çerçevesinde incelenmiş ve tümcedeki bütün AÖ'lerin toplam sesletim süreleri ve temel s1klık değerleri hesaplanmıştır.

İşitsel uyaranın çaprazlama işlemi sırasında, çaprazlanmaya hazır hale getirilen ses kayıtlarının sıfır geçiş noktaları, PRAAT 5.2 Ses Çözümleme Programı kullanılarak sabit tutulmakta ve sıfır geçiş noktalarının genlik ve 
yoğunluk değerleri belirlenmektedir. Çaprazlama sırasında karışıklık oluşmaması için her bir ses kaydına ait ayrı kodlarla adlandırılan kayıt dosyaları oluşturulması önerilmektedir. Bu araştırmada tartışılacak olan işitsel uyaranlar, Türkçede eylem-sonu konumunda bürün-sözdizim etkileşimini araştıran ve aynı özellikte oluşturulan iki ayrı deney setinden alınmıştır. Eylem-sonu konumunda deney koşulları bürünsel özellikleri çerçevesinde ikiye bölütlenmiştir. Buna göre, ilk çaprazlama grubu bürünsel bozulma koşulu ve bürün-sözdizim bozulması koşulu; ikinci grup ise dilbilgisel koşul ve sözdizim bozulması koşulu biçiminde sınıflandırılmıştır. Bu sınıflandırmanın temel nedeni, bürünsel açıdan eylem-öncesi konumundaki AÖ'lerin benzer özellikleri taşıyor olmasıdır. Bekâr (2016)'da belirtildiği gibi, örneğin bürünsel ve sözdizim açıdan düzgün olarak tanımlanan Dilbilgisel koşulu gösteren [Kapıcı [BAHÇEDE ODAK] çırptı [kilim-i Kritik Aö]] tümcesiyle, Sözdizim Bozulması koşulunu taşıyan [Kapıc1 [BAHÇEDE ODAK] çırptı [kilim-e Kritik AÖ]] tümcesi bürünsel açıdan benzer özelliklere sahiptir. Bu tümcelerin doğal ses kaydına dönüştürülmesi sırasında kritik sözcügüun sesletimine kadar eylem-öncesi konumlarının sabit kalabilmesi için Dilbilgisel koşuldaki kritik AÖ tümceden çıkarılmıştır. Bu koşul, eylem-öncesi (a) ve eylem-sonu kritik AÖ'sü (b) biçiminde iki ayrı dosyaya kodlanarak kaydedilmiştir. Benzer işlem, Sözdizim Bozulması gösteren koşuldaki tümce için de eylem-öncesi (a) ve eylem-sonu kritik AÖ'sü (b) olarak gerçekleştirilmiştir. Ardından, Sözdizim Bozulması koşulundaki tümcenin kritik AÖ'sü ile Dilbilgisel koşuldaki tümcenin eylem-öncesi konumu sıfır geçiş noktaları çerçevesinde birbirine sabitlenerek çaprazlanmıştır. İşitsel uyaran setinin ikinci çaprazlama grubu Bürün Bozulması koşulu [Kapıcı bahçede çırptı [KİLİM-İ Kritik Aö]] ve Bürün-Sözdizim Bozulması koşulu [Kapıcı bahçede çırptı [KİLİM-E Kritik Aö]] için de benzer bir ÇBU yöntemi uygulanmıştır. Böylelikle her ikii işitsel uyaran grubunun kritik AÖ'leri hem biten ezgi ile eylem-sonu konumunda üretilmiş, hem de tümcelerin eylemöncesi konumları aynı fiziksel özellikleri taşıyor hale getirildiği için katılımcıların dikkat odağı yalnızca kritik AÖ'ler üzerinde tutulmuştur. İşitsel uyaranların çaprazlanması işlemleri tamamlandığında ise, bütün ses kayıtları genlik, yoğunluk, sesletim süreleri, temel sıklık değerleri açısından ayrı ayrı kontrol edilmiş ve tüm kayıtlar şaklama, tıklama sesinin olmamasına özellikle özen gösterilmiştir.

\section{Uygulama}

\subsection{Akustik Analiz}

Deneylerin akustik ses kayıt işlemleri anadili Türkçe olan bir kadın uzman tarafından Ankara Üniversitesi Beyin Araştırmaları Uygulama ve Araştırma Merkezi'nde bulunan Dilbilim Laboratuvarı'nda gerçekleştirilmiştir. Ses 
kayıtları, Shure Beta dinamik mikrofon kullanılarak 44.100 örnekleme oranı ve 16 bit çözünürlükte PCM.wav formatında Adobe Audition Pro ve PRAAT 5.2 Ses Analizi programlarında kaydedilmiş ve çözümlenmiştir. Her iki deneyin de işitsel uyaranlarının EEG deneylerinde kullanılabilmesi için MatLab yazılımının Psych araç kutusu kullanılmıştır. İşitsel Uyaran Seti (1)'de yukarıdaki bölümlerde sözü edilen ÇBU yöntemi kullanılmadan kaydedilen doğal ses kaydı üzerinde akustik çözümleme gerçekleştirilmiştir. İşitsel Uyaran Seti (2)'de ise, MatLab yazılımına işitsel uyaranlar kaydedilmeden önce akustik önişlemlemeden geçirilmiş ve çaprazlama işlemi uygulanmıştır. Bu işlemlemenin ardından ses kayıtları MatLab'ın araç kutusunda EEG deneylerinde kullanıma hazır hale getirilmiştir.

EEG deneylerine başlamadan, işitsel uyaran setleri hem akustik hem de istatistiksel çerçevede çözümlenmiş ve uyaran setlerinin EEG deneylerine uygun olarak hazırlanıp hazırlanmadığı sınanmıştır. Bu çözümleme sırasında tüm deney tümceleri tümce-başı, eylem-öncesi, eylem ve eylem-sonu konumlarındaki temel sıklık (Hz) ve sesletim süresi (ms) değerleri açısından deney koşullarına göre SPSS istatistiksel analiz yazılımı aracılığıyla karşılaştırılmıştır. ${ }^{6}$

\subsection{Istatistiksel Analiz}

Deneylerin istatistiksel çözümlemesi için SPSS 18.0 Yazılımı kullanılmış, davranışsal veri ve akustik çözümleme için farklı istatistiksel çözümleme yöntemlerine başvurulmuştur. Buna göre, EEG deneyleri sırasında MatLab Yazılımı aracılığıyla çevrimiçi olarak toplanan davranışsal veriler parametrik olmayan çok yönlü Friedman S Testi çerçevesinde analiz edilmiştir. Friedman S Testi parametrik olmayan verileri çözümlemek amaciyla uygulanan bir yöntemdir. Bununla birlikte, yukarıdaki bölümde sunulan deney koşulları (Dilbigisel Koşul, Bürün Bozulması Koşulu, Sözdizim Bozulması Koşulu, Bürün-Sözdizim Bozulması Koşulu) arasındaki temel anlamlılık seviyelerinin belirlenebilmesi için çift yönlü Wilcoxon Testi uygulanmıştır. Buna göre, birbirine bağımlı iki koşulun aynı dağılımsal görünümleri gösterip göstermediğini ortaya konabilmektedir.

EEG deneyleri sırasında sunulan işitsel uyaranların akustik çözümlemeleri için ise deney koşulları arasındaki anlamlılık seviyelerini ve koşul ortalamaları arasında temel bir farklılık olup olmadığını ortaya koyabilmek

6 Akustik çözümlemeler sırasında aynı zamanda deney tümcelerini oluşturan her bir öbeğin başlangıç noktaları ve kritik AÖ'nün seslem başlangıçları da belirlenmiştir. Ancak bu işlemleme doğrudan MatLab Yazılımında EEG deneyleri için tetik kodlarının hazırlanması aşamasıyla ilişkili olduğu için bu çalışmada söz edilmeyecektir. Bu konuda ayrıntılı bilgi için bkz. Bekâr (2016). 
amacıyla Bağımsız Örneklem T-Testi (Independent Samples T-Test) uygulanmıştır. Bütün istatistiksel çözümlemelerde anlamlılık değeri $\mathrm{p}<0.05$ olarak kabul edilmiştir.

\section{Bulgular}

\section{1 İşitsel Uyaranların Çözümlenmesi}

EEG deneylerinde MatLab yazılımının Psych araç kutusu kullanılarak sunulan işitsel uyaranlar, deneylerden önce istatistiksel olarak çözümlenmiştir. Sesletim süresi (ms) ve temel sıklık (Hz) değerleri açısından incelenen işitsel uyaranlar, aşağıda sunulan tablo ve şekillerde İşitsel Uyaran Seti (1) ve İşitsel Uyaran Seti (2)'ye ilişkin setler çerçevesinde yorumlanmaktadır. Her iki deneyde de, akustik inceleme iki aşamada gerçekleştirilmiştir. İlk olarak akustik analizde değerlendirilecek değiştirgenler PRAAT 5.2 Ses Analizi Yazılımında sayısal olarak sesletim süreleri ve temel sıklık değerleri açısından hesaplanmaya hazır hale getirilmiştir. Bunun ardından, deney tümcelerinin her biri tümcedeki konumları açısından tümce-başı, eylem-öncesi, eylem ve eylem-sonu biçiminde dört ayrı konumda incelenmiştir. ${ }^{7} \mathrm{Bu}$ aşama tamamlandıktan sonra, veriler SPSS İstatistiksel Analiz Programında deney koşulları arasındaki farklılığı gözlemlemek amacıyla Bağımsız Örneklem T-Testi ile değerlendirilmiştir. Buna göre, işitsel uyaranlar KOŞUL [(Dilbilgisel Koşul, Bürün Bozulması Koşulu, Sözdizim Bozulması Koşulu, Bürün-Sözdizim Bozulması Koşulu)], KONUM [(tümce-başı, eylem-öncesi, eylem, eylem-sonu)] ve DEĞİŞTİRGEN [(temel sıklık, sesletim süresi)] olmak üzere kendi içinde üç aşamalı olarak çözümlenmiştir.

\subsubsection{Sesletim Sürelerinin (ms) İstatistiksel Değerlendirmesi}

Bu bölümde, İşitsel Uyaran Seti (1) ve İşitsel Uyaran Seti (2)'ye ait işitsel uyaranların deney koşulları ve tümcedeki sözdizimsel konumları arasında sesletim sürelerine (ms) dayalı olarak oluşan Bağımsız Örneklem T-Testi bulguları ayrıntılı olarak sunulmaktadır. Aşağıda Tablo 2'de sunulan İşitsel Uyaran Seti (1)'in işitsel uyaranlarına ait tümce-başı konumunda tüm deney koşullarına ilişkin $t$ değerleri ve ortalamalar, [Dilbilgisel (Ort. $=0.48) \times$ Bürün Bozulmas1 (Ort. $=0.47)>\left(\mathrm{t}_{0,05: 98}=1.25\right)$, Dilbilgisel $\times$ Sözdizim Bozulmas1 $(\mathrm{Ort}=0.47)>(\mathrm{t}=1.07)$, Dilbilgisel $\times$ Bürün-Sözdizim Bozulması $($ Ort. $=0.46)>$ $(\mathrm{t}=1.58)$ değerinde; eylem-öncesi konumunda Dilbilgisel (Ort. $=0.53) \times$ Bürün

$7 \mathrm{Bu}$ süreçte, birimlerin tek tek sözcük başlangıç süreleri de ayrıntılı olarak hesaplanmıştır. Ancak bu veriler EEG deneylerine ilişkin uyaranların tetik kodları için gerekli olduğundan bu çalışma kapsamında söz edilmemektedir. 
Bozulmas1 (Ort. $=0.50)>(\mathrm{t}=1.91)$, Dilbilgisel $\times$ Sözdizim Bozulmas1 $($ Ort. $=0.51)>(\mathrm{t}=1.56)$, Dilbilgisel $\times$ Bürün-Sözdizim Bozulması $($ Ort. $=0.52)>$ $(\mathrm{t}=9.83)$ değerinde; eylem konumunda Dilbilgisel $($ Ort. $=0.48) \times$ Bürün Bozulmas1 (Ort. $=0.50)>(\mathrm{t}=1.73)$, Dilbilgisel $\times$ Sözdizim Bozulmas1 $($ Ort=0.47 $)>(t=1.01)$, Dilbilgisel $\times$ Bürün-Sözdizim Bozulması $($ Ort.=0.49) $>$ $(\mathrm{t}=1.07)$ değerinde ve son olarak eylem-sonu konumunda Dilbilgisel (Ort. $=0.54)$ $\times$ Bürün Bozulması $($ Ort. $=0.56)>(\mathrm{t}=2.59)$, Dilbilgisel $\times$ Sözdizim Bozulması $(\mathrm{Ort}=0.52)>(\mathrm{t}=1.12)$, Dilbilgisel $\times$ Bürün-Sözdizim Bozulması $($ Ort. $=0.56)>$ $(\mathrm{t}=2.92)$ değerindedir.

Tablo 2. İşitsel Uyaran Seti (1)'e ilişkin sesletim sürelerinin istatistiksel değerleri

\begin{tabular}{|c|c|c|c|c|c|c|c|c|c|}
\hline \multicolumn{2}{|c|}{ Deney Koşulları } & \multicolumn{2}{|c|}{ Tümce-Başı } & \multicolumn{2}{|c|}{ Eylem-Öncesi } & \multicolumn{2}{|c|}{ Eylem } & \multicolumn{2}{|c|}{ Eylem-Sonu } \\
\hline & & $F$ & $p$ & $F$ & $p$ & $F$ & $p$ & $F$ & $p$ \\
\hline \multirow{3}{*}{ Dilbilgisel } & $\begin{array}{c}\text { Bürün } \\
\text { Bozulmast }\end{array}$ & 0.770 & $>.05$ & 0.941 & $>.05$ & 0.375 & $>.05$ & 0.000 & $>.05$ \\
\hline & $\begin{array}{c}\text { Sözdizim } \\
\text { Bozulmasl }\end{array}$ & 0.000 & $>.05$ & 1.828 & $>.05$ & 0.358 & $>.05$ & 0.024 & $>.05$ \\
\hline & $\begin{array}{c}\text { Bürün- } \\
\text { Sözdizim } \\
\text { Bozulmast }\end{array}$ & 0.026 & $>.05$ & 0.834 & $>.05$ & 0.043 & $>.05$ & 0.678 & $<.05$ \\
\hline
\end{tabular}

Tablo 3 'te sunulan İşitsel Uyaran Seti (2)'nin işitsel uyaranlarına ait tümce-başı konumunda tüm deney koşullarına ilişkin t değerleri ve ortalamalar, Dilbilgisel için $($ Ort. $=0.37) \times$ Bürün Bozulması $($ Ort. $=0.36)>\left(\mathrm{t}_{0,05: 98}=0.66\right)$, Dilbilgisel $\times$ Sözdizim Bozulması (Ort. $=0.37)>(\mathrm{t}=0.00)$, Dilbilgisel $\times$ Bürün-Sözdizim Bozulmas1 (Ort. $=0.36)>(\mathrm{t}=0.70)$ değerinde; eylem-öncesi konumunda Dilbilgisel (Ort. $=0.41) \times$ Bürün Bozulması (Ort. $=0.40)>(\mathrm{t}=1.32)$, Dilbilgisel $\times$ Sözdizim Bozulması (Ort. $=0.41)>(\mathrm{t}=0.08)$, Dilbilgisel $\times$ Bürün-Sözdizim Bozulmas1 (Ort. $=0.40)>(\mathrm{t}=0.00)$ değerinde; eylem konumunda Dilbilgisel $($ Ort. $=0.36) \times$ Bürün Bozulması $($ Ort. $=0.38)>(\mathrm{t}=2.10)$, Dilbilgisel $\times$ Sözdizim Bozulmas1 (Ort. $=0.36)>(\mathrm{t}=0.02)$, Dilbilgisel $\times$ Bürün-Sözdizim Bozulmas1 $($ Ort. $=0.38)>(\mathrm{t}=2.05)$ değerinde; eylem-sonu konumunda Dilbilgisel $($ Ort. $=0.42) \times$ Bürün Bozulması $($ Ort. $=0.48)>(\mathrm{t}=5.64)$, Dilbilgisel $\times$ Sözdizim Bozulmas1 (Ort. $=0.44)>(\mathrm{t}=2.32)$, Dilbilgisel $\times$ Bürün-Sözdizim Bozulması $($ Ort. $=0.48)>(\mathrm{t}=5.87)$ değerindedir. 
Tablo 3. Işsitsel Uyaran Seti (2)'ye ilişkin sesletim sürelerinin istatistiksel değerleri

\begin{tabular}{ccccccccccc}
\hline & \multicolumn{2}{c}{ Tümce-Başı } & Eylem-Öncesi & \multicolumn{2}{c}{ Eylem } & \multicolumn{2}{c}{ Eylem-Sonu } \\
\cline { 2 - 10 } Deney Koşulları & $F$ & $p$ & $F$ & $p$ & $F$ & $p$ & $F$ & $p$ \\
\hline \multirow{2}{*}{ Dilbilgisel } & $\begin{array}{c}\text { Bürün } \\
\text { Bozulmasl }\end{array}$ & 0.057 & $>.05$ & 0.003 & $>.05$ & 0.946 & $<.05$ & 4.316 & $<.05$ \\
\cline { 2 - 9 } & $\begin{array}{c}\text { Sözdizim } \\
\text { Bozulmasl }\end{array}$ & 0.000 & $>.05$ & 0.020 & $>.05$ & 0.050 & $>.05$ & 0.194 & $<.05$ \\
\hline $\begin{array}{c}\text { Bürün- } \\
\text { Sözdizim } \\
\text { Bozulmasl }\end{array}$ & 0.054 & $>.05$ & 0.000 & $>.05$ & 1,422 & $<.05$ & 0.768 & $<.05$ \\
\hline
\end{tabular}

İşitsel Uyaran Seti (1) ve İşitsel Uyaran Seti (2)'nin işitsel uyaranlarına ait sesletim sürelerinin istatistiksel farklılıklarının sunulduğu Tablo 2 ve Tablo 3 'te koşullara ait dağılımsal farklılıklar ortaya konulmaktadır. Odaklamanın sesletim süresini değiştirebilmesi nedeniyle, özellikle bürünsel bozulma ve bürün-sözdizim bozulması içeren koşullarla, dilbilgisel ve sözdizimsel bozulma koşulları arasında istatistiksel bir anlamlılık oluşması beklenmektedir. Buna göre, tamamen doğal konuşma kayıtlarından ve işitsel uyarandaki bütün deney tümcelerinin ayrı ayrı sesletildiği İşitsel Uyaran Seti (1)'e ait sesletim süresi karşılaştırmasında hiçbir birim arasında anlamlı bir farklılık oluşmadığı dikkat çekmektedir. Ancak deney koşulları arasında bürün bozulması ve bürünsözdizim bozulması koşullarında eylem-sonu konumlarındaki AÖ'lerin, diğer deney koşullarındaki AÖ'lere göre daha baskın bir şekilde sesletilmesi beklenildiğinden, sesletim süreleri arasında bir anlamlılık oluşması gerekmektedir. Bu durumda, İşitsel Uyaran Seti (1)'in işitsel uyaranlarının hep aynı uzunlukta sesletildiği görülmektedir. Öte yandan, ÇBU yönteminin kullanıldığı İşitsel Uyaran Seti (2)'nin işitsel uyaranlarına ait tümcedeki birimler ve deney koşulları arasında ise belirgin bir anlamlılık oluştuğu gözlemlenmektedir. Elde edilen bu bulgular oluşması beklenildiği gibi, bürünsel bozulma, sözdizimsel bozulma ve bürün-sözdizim bozulması koşulları ile dilbilgisel koşul arasında anlamlı görünmektedir. Benzer şekilde eylemsonunun hemen öncesinde eylem üzerinde de özellikle bürünsel bozulmanın yer aldığ 1 koşullarda ortaya çıkmaktadır. Dolayısıyla, eylem-sonu konumunda gerçekleştirilen bürünsel bozulmayı oluşturan AÖ'lerin yerinde bir biçimde oluşturulduğu ve işitsel uyaranlarla deney koşulları arasında dengeli bir süre farklılıği oluştuğu, her koşulun dilbilimsel amacına uygun olarak katılımcıya sunulmaya hazır hale getirildiği göze çarpmaktadır. Tablo 4'te ve Tablo 5'te ise, sesletim süresi ve deney koşullarının tümcedeki konumlarla arasındaki 
dağılımsal örüntüyü gösteren ortalama ve standart yanlış oranları aşağıda sunulmaktadir.

Tablo 4'te ve Tablo 5'te sunulan ortalama değerler ve standart yanlış oranlarından da açıkça gözlemleneceği gibi, İşitsel Uyaran Seti (1)'in işitsel uyaranlarının daha düzensiz, ancak İşitsel Uyaran Seti (2)'nin işitsel uyaranların buna nazaran daha dengeli bir dağılım gösterdiği görülmektedir.

Tablo 4. Işsitsel Uyaran Seti (1)'e ilişkin sesletim sürelerinin ortalama ve standart yanlış oranları

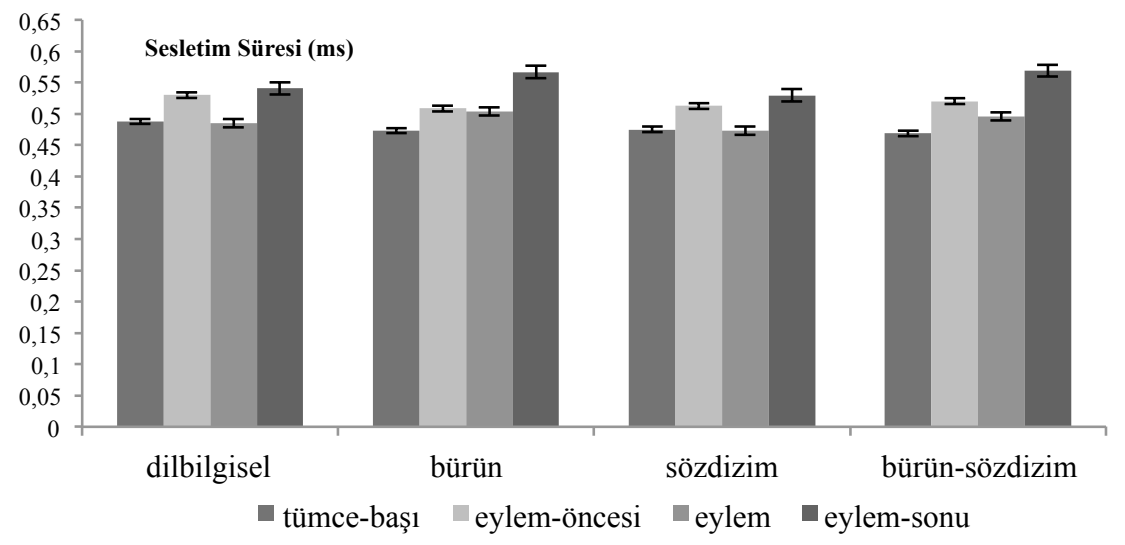

Tablo 5. İsitsel Uyaran Seti (2)'ye ilişkin sesletim sürelerinin ortalama ve standart yanlış oranları

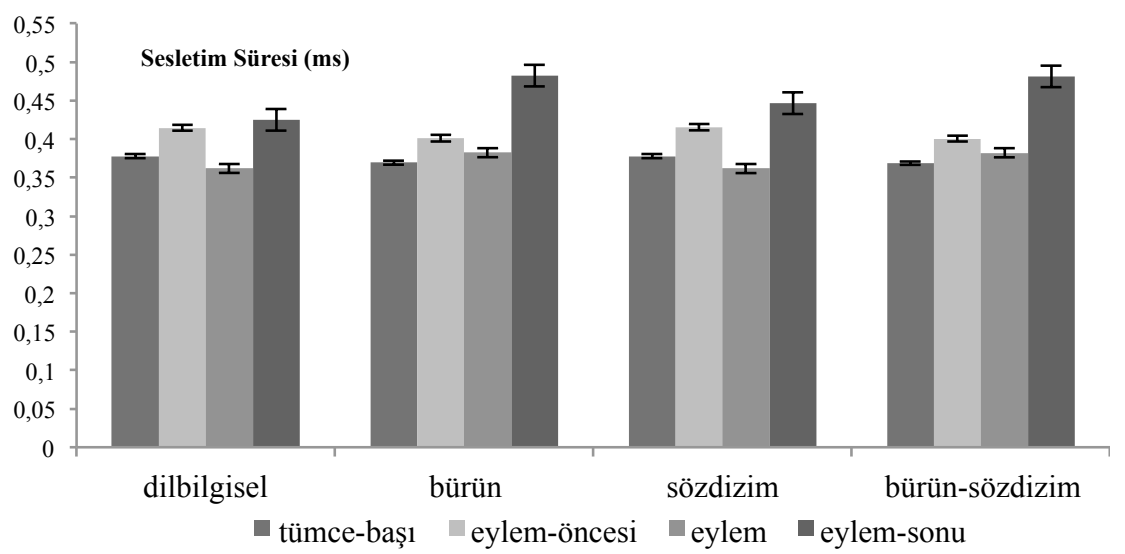






İşitsel Uyaran Seti (1) ve İşitsel Uyaran Seti (2)'ye ait işitsel uyaranların deney koşulları ve tümcedeki sözdizimsel konumları arasındaki temel sıklık farklılıklarını gösteren Bağımsız Örneklem T-Testi bulguları göre, ilk olarak aşağıda Tablo 6'da sunulan İşitsel Uyaran Seti (1)'in işitsel uyaranlarına ait tümce-başı konumunda tüm deney koşullarına ilişkin $t$ değerleri ve ortalamalar, Dilbilgisel (Ort.=187.42) $\times$ Bürün Bozulmas1 (Ort.=161.15) $>\left(\mathrm{t}_{0,05: 98}=8.63\right)$, Dilbilgisel $\times$ Sözdizim Bozulması $($ Ort. $=171.79)>(\mathrm{t}=5.32)$, Dilbilgisel $\times$ Bürün-Sözdizim Bozulması (Ort.=157.34) > $(\mathrm{t}=9.46)$ değerinde; eylem-öncesi konumunda Dilbilgisel (Ort.=180.45) × Bürün Bozulması (Ort.=155.50) > $(\mathrm{t}=5.95)$, Dilbilgisel $\times$ Sözdizim Bozulması (Ort.=171.18) $>(\mathrm{t}=2.90)$, Dilbilgisel $\times$ Bürün-Sözdizim Bozulması (Ort.=152.37) $>(\mathrm{t}=9.05)$ değerinde; eylem konumunda Dilbilgisel için (Ort.=125.84) $\times$ Bürün Bozulmas1 $($ Ort. $=150.97)>(t=9.38)$, Dilbilgisel $\times$ Sözdizim Bozulması $($ Ort=123.47) $>$ $(\mathrm{t}=1.01)$, Dilbilgisel $\times$ Bürün-Sözdizim Bozulması $($ Ort. $=145.06)>(\mathrm{t}=8.12)$ ve eylem-sonu konumunda Dilbilgisel (Ort.=100.65) $\times$ Bürün Bozulmas1 $($ Ort. $=131.49)>(\mathrm{t}=19.49)$, Dilbilgisel $\times$ Sözdizim Bozulması $($ Ort=100.95 $)>$ $(\mathrm{t}=0.18)$, Dilbilgisel $\times$ Bürün-Sözdizim Bozulması $($ Ort. $=124.88)>(\mathrm{t}=15.38)$ değerindedir.

Tablo 6. İşitsel Uyaran Seti (1)'e ilişkin temel sıklık değerlerinin istatistiksel değerleri

\begin{tabular}{ccccccccccc}
\hline & \multicolumn{3}{c}{ Tümce-Başı } & Eylem-Öncesi & \multicolumn{2}{c}{ Eylem } & \multicolumn{2}{c}{ Eylem-Sonu } \\
\cline { 2 - 10 } Deney Koşulları & $F$ & $p$ & $F$ & $p$ & $F$ & $p$ & $F$ & $p$ \\
\hline \multirow{2}{*}{ Dilbilgisel } & $\begin{array}{c}\text { Bürün } \\
\text { Bozulması }\end{array}$ & 7.402 & $<.05$ & 0.419 & $>.05$ & 1.096 & $>.05$ & 0.079 & $>.05$ \\
\cline { 2 - 9 } & $\begin{array}{c}\text { Sözdizim } \\
\text { Bozulmasl }\end{array}$ & 10.621 & $<.05$ & 3.527 & $>.05$ & 0.817 & $>.05$ & 0.178 & $>.05$ \\
\cline { 2 - 6 } & $\begin{array}{c}\text { Bürün- } \\
\text { Sözdizim } \\
\text { Bozulmasl }\end{array}$ & 2.920 & $>.05$ & 5.820 & $<.05$ & 0.815 & $>.05$ & 0.075 & $>.05$ \\
\hline
\end{tabular}

İşitsel Uyaran Seti (2)'de tümce-başı konumunda tüm deney koşullarına ilişkin t değerleri ve ortalamalar, Dilbilgisel (Ort.=241.75) $\times$ Bürün Bozulmas1 $($ Ort. $=232.35)>\left(\mathrm{t}_{0,05: 98}=2.89\right), \quad$ Dilbilgisel $\times$ Sözdizim Bozulmas1 $(\mathrm{Ort}=241.75)>(\mathrm{t}=0.00), \quad$ Dilbilgisel $\times$ Bürün-Sözdizim Bozulmas1 $($ Ort. $=232.48)>(\mathrm{t}=2.86)$ değerinde; eylem-öncesi konumunda Dilbilgisel $($ Ort.=238.36) $\times$ Bürün Bozulması $($ Ort.=243.68) $>(\mathrm{t}=1.83)$, Dilbilgisel $\times$ Sözdizim Bozulması (Ort. $=237.61)>(\mathrm{t}=0.29)$, Dilbilgisel $\times$ Bürün-Sözdizim Bozulmas1 (Ort. $=243.36)>(\mathrm{t}=1.72)$ değerinde; eylem konumunda Dilbilgisel 
$($ Ort. $=176.87) \times$ Bürün Bozulması $($ Ort. $=190.75)>(t=3.91)$, Dilbilgisel $\times$ Sözdizim Bozulması (Ort=177.35) $>(\mathrm{t}=0.24)$, Dilbilgisel $\times$ Bürün-Sözdizim Bozulmas1 (Ort.=192.11) $>(\mathrm{t}=4.12)$ değerinde; eylem-sonu konumunda Dilbilgisel (Ort.=154.49) $\times$ Bürün Bozulmas1 (Ort.=180.24) > $(\mathrm{t}=11.95)$, Dilbilgisel $\times$ Sözdizim Bozulması $($ Ort $=155.67)>(\mathrm{t}=0.95)$, Dilbilgisel $\times$ Bürün-Sözdizim Bozulması (Ort. $=174.16)>(\mathrm{t}=9.53)$ değerindedir.

Tablo 7. İsitsel Uyaran Seti (2)'ye ilişkin temel sıklık değerlerinin istatistiksel değerleri

\begin{tabular}{ccccccccccc}
\hline & \multicolumn{1}{c}{ Tümce-Başı } & $\begin{array}{c}\text { Eylem- } \\
\text { Oncesi }\end{array}$ & Eylem & \multicolumn{2}{c}{ Eylem-Sonu } \\
\cline { 2 - 9 } Deney Koşulları & $F$ & $p$ & $F$ & $p$ & $F$ & $p$ & $F$ & $p$ \\
\hline \multirow{2}{*}{ Dilbilgisel } & $\begin{array}{c}\text { Bürün } \\
\text { Bozulmastizim } \\
\text { Bozulmast }\end{array}$ & 0.415 & $<.05$ & 2.212 & $>.05$ & 32.201 & $<.001$ & 16.134 & $<.001$ \\
\hline $\begin{array}{c}\text { Bürün- } \\
\text { Sözdizim } \\
\text { Bozulmast }\end{array}$ & 0.252 & $<.05$ & 2.708 & $>.05$ & 40.588 & $<.001$ & 22.351 & $<.001$ \\
\hline
\end{tabular}

Deney koşullarının birbirinden farklı olmasını sağlayan en temel akustik değiştirgenlerden biri Beckman (1996)'da belirtildiği gibi, temel sıklık değeridir. Bir önceki bölümde sesletim süreleri arasında çok keskin olmasa da, işitsel uyaranların oluşturulma yönteminden ötürü, özellikle İşitsel Uyaran Seti (1)'de koşulların birbirinden farklı olduğunu belirten bir anlamlılık değerine ulaşılmadığı görülmüştür. Benzer durum, Tablo 7'de sunulan işitsel uyaranların temel sıklık değerlerine ait istatistiksel bulgularda da açıkça ortaya konmaktadır. Odaklamanın koşullar arasında farklılığını gösteren temel sıklık değeri, Tablo 6'da yalnızca tümce-başı konumunda bürün bozulma ve sözdizimsel bozulma koşullarında ve eylem-öncesi konumunda bürünsel ve sözdizimsel bozulma koşulunda düşük oranda bir farklılık oluşturmaktadır. Ancak bu durum, bürünsel bozulmanın temelde görülmesi beklenen eylem ya eylem-sonu konumlarında herhangi bir değişim sunmamaktadır. Elde edilen bu bulgular İşitsel Uyaran Seti (1)'e ait işitsel uyaranlar arasındaki bürünsel farklılığın anlaşılabilirliğini yüksek oranda zayıflatmaktadır. Öte yandan, ÇBU yöntemi ile oluşturulan İşitsel Uyaran Seti (2)'ye ait işitsel uyaranların temel sıklık değerleri incelendiğinde, olması beklenildiği gibi, eylem-öncesi konumunda herhangi bir farklılık oluşmaması ve bürünsel bozulmanın gerçekleştiği eylem-sonu konumunda yüksek oranda bir farklılık olması dikkate değer bir bulgudur. $\mathrm{Bu}$ durumda, işitsel uyaranların bürünsel bozulma içeren koşullarla bürünsel bozulma içermeyen koşullar arasında istatistiksel olarak 
anlamlı bir şekilde dağıldığı ve katılımcıların deneydeki sesbilimsel farklılıkları açıkça fark edebilmesine zemin hazırlandığı görülmektedir. Benzer dağılımsal farklılık aşağıda Tablo 8'deki İşitsel Uyaran Seti (1)'e ait işitsel uyaranlarda ve Tablo 9'daki ÇBU yöntemi ile oluşturulan İşitsel Uyaran Seti (2)'ye ait işitsel uyaranların deney koşulları ve tümcedeki konumlar arasındaki farklılıklarından açıkça görülebilmektedir.

Tablo 8. İşitsel Uyaran Seti (1)'e ilişkin temel sıklık dĕgerlerinin ortalama ve standart yanlış oranlarl

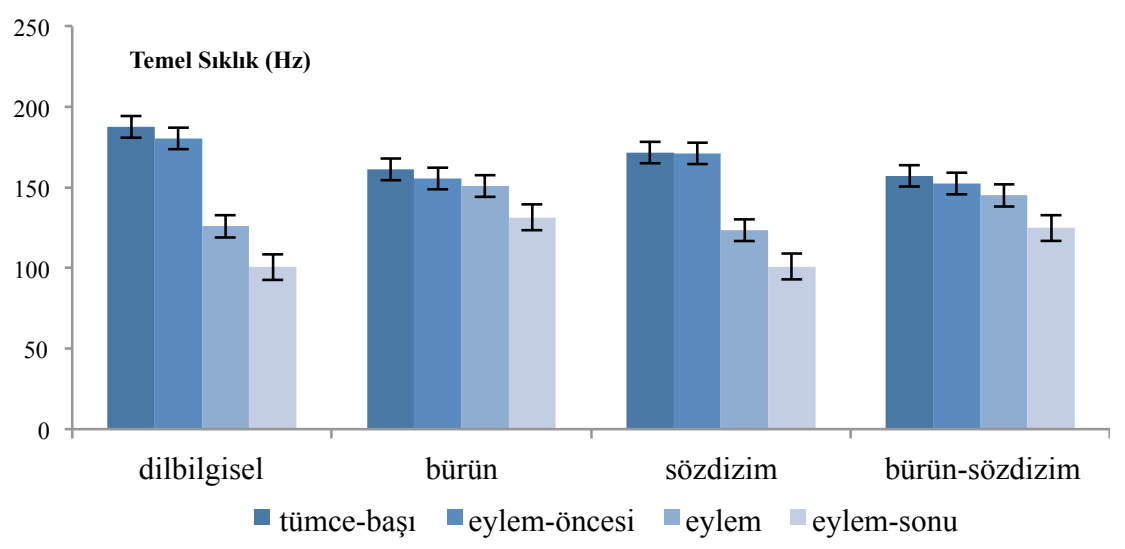

Tablo 9. İşitsel Uyaran Seti (2)'ye ilişkin temel sıklık değerlerinin ortalama ve standart yanlış oranlarl

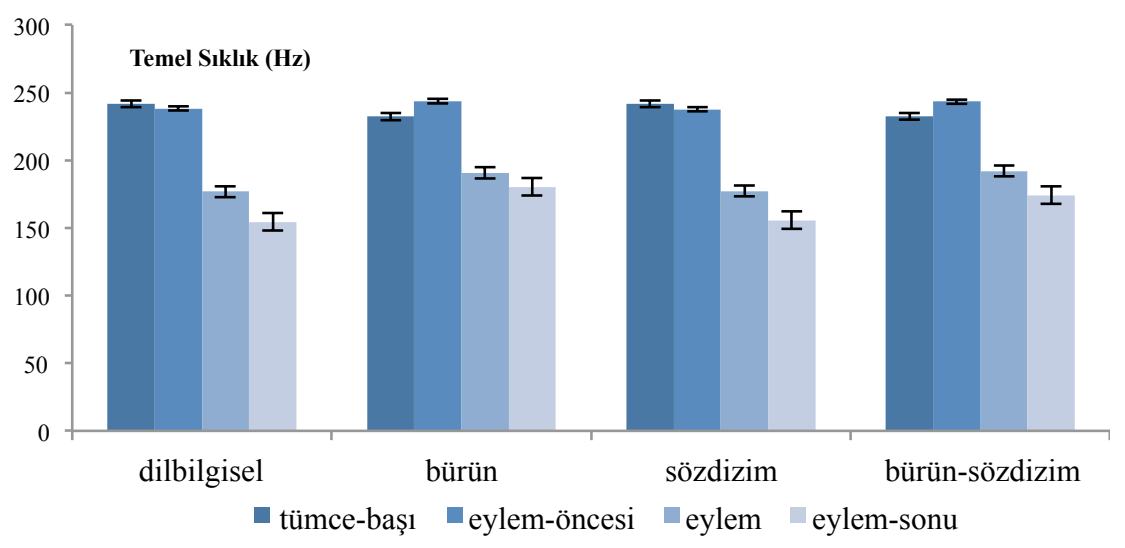




\section{6 ÇBU Yönteminin Süreç-Dışı ve Süreç-Ị̇ci Bulgulara Etkisi}

$\mathrm{Bu}$ bölümde, ÇBU yönteminin uygulandı̆̆ $\mathrm{EEG}$ deneyine ait süreç-dışı bulguların yorumlandığı davranışsal veri analizleri ve süreç-içi EEG bulgularının olaya ilişkin beyin potansiyelleri üzerinde durulmaktadır. $\mathrm{Bu}$ kapsamda öncelikli olarak, aşağıda işitsel uyaran setleri kullanılarak gerçekleştirilen EEG deneylerine ilişkin deney yöntemleri sunulduktan sonra, süreç-dışı ve süreç-içi bulguların ÇBU yöntemine göre nasıl bir değişim gösterdiği tartışılacaktır.

\subsection{EEG Deneylerinin Hazırlanması}


Ankara Üniversitesi Beyin Araştırmaları Uygulama ve Araştırma Merkezi'ndeki EEG Laboratuvarı'nda gerçekleştirilmiştir. İşitsel Uyaran Seti (1) ile kurulmuş olan Deney (1)'e 18 gönüllü katılımcı (10 kadın, 8 erkek $~ 28.2$ yaş ortalaması) alınmış, İşitsel Uyaran Seti (2) ile oluşturulan Deney (2)'ye ise 29 gönüllü katılımcı (26 kadın, 14 erkek $\sim 23.1$ yaş ortalaması) alınmıştır. Anadilleri Türkçe olan tüm katılımcılar 18-35 yaş aralığında, nörolojik ya da psikiyatrik bir sorunu olmayan, işitme ya da ileri düzeyde görme kaybı olmayan, en az yüksek öğretim düzeyinde öğrenim görmüş sağ el baskını bireylerden oluşmaktadır.

İşitsel uyaranlardan oluşan $2 \times 2$ deney desenindeki toplam 300 tümcenin 200'ü deney, 100'ü dolgu tümcelerinden oluşmaktadır. Her deney koşulunda toplam 50'şer tümce bulunmaktadır. Çözümlemeler sırasında deney tümceleri 50'şer tümcelik setler halinde karşılaştırılmıştır. Ancak deneyde kullanılan bütün tümceler arasında bir denge sağlanması gerektiğinden dolgu tümceleri deneydeki Dilbilgisel Koşul ile aynı biçimde oluşturulmuştur. Bu durumda deney sirasında katılımcılar toplam 150 düzgün tümce (Dilbilgisel Koşul ve dolgu tümceleri) ve 150 bozuk tümce (Bürün Bozulması Koşulu, Sözdizim Bozulması Koşulu, Bürün-Sözdizim Bozulması Koşulu) işitmiştir.

Her iki araştırmanın da sesel uyaranları, işitsel teknik kullanılarak Psych araç kutusu ile MatLab Yazılımında hazırlanmıştır. Koyu siyah zemin üzerinde ekrana yansıtılan fiksasyon (artı işareti) aracılığıyla sunulan deneylerde beyaz ve açık mavi olmak üzere iki ayrı fiksasyon tercih edilmiştir. Katılımcıdan deney tümcelerini dinlerken beyaz fiksasyona, yanıt ekranı çıktığında ise açık mavi fiksasyona dikkatlice bakması istenmiştir. Uyaran ekranına yaklaşık $70 \mathrm{~cm}$ uzaklıkta oturtulan tüm katılımcılara işitsel uyaran Senheisser model profesyonel kulaklık ile dinletilmiş ve katılımcıları mouse aracılığıyla tümcelere yanıt vermeleri istenmiştir.

Temel deneyler başlamadan önce her iki araştırmada da katılımcılardan 10 tümcelik rastlantısal alıştırma deneyi yapmaları istenmiştir. Bunun ardından katılımcıların deneyleri algilama seviyesi kontrol edilerek, temel deneyler 
başlatılmıştır. 300 tümceden oluşan temel deneylerde toplam 5 adet eşit uzun dinlenim arası kullanılmış, deneyler yaklaşık 60 dakikada tamamlanmıştır. İşitsel uyaran başladığı sırada, Şekil 4'te görüleceği gibi, koyu siyah zeminli ekranın orta kısmına 500 ms süresince beyaz fiksasyon verilmiş ve bu sürenin sonunda katılımcılara işitsel uyaran sunulmuştur. Uyaran $1500 \mathrm{~ms}$ içinde bitmiş ve bu sürenin bitmesinden $2000 \mathrm{~ms}$ sonrasına kadar ekranda beyaz fiksasyon işareti tutulmuştur. Bu sırada ekrana pür dikkat bakması istenen katılımcıya $3000 \mathrm{~ms}$ süre boyunca ekranda duracak olan yanıt fiksasyonu, başka deyişle açık mavi fiksasyon sunulmuştur. Katılımcı bu sırada duyduğu tümce dilbilgisel olarak kabuledilebilir ise mouse kullanarak sol tuşa, tümce bozuksa sağ tuşa basmıştır. Bu sürenin sonunda ise, EEG deneylerinde kullanılan uluslararası uyaranlararası 1500 ms'lik süre (interstimulus interval) verilmiş ve bir sonraki işitsel uyarana geçilmiştir. Bu şekilde toplam 300 tümcelik deney ve dolgu uyaranları rastlantısal olarak katılımcılara aynı prosedür çerçevesinde sunulmuştur.

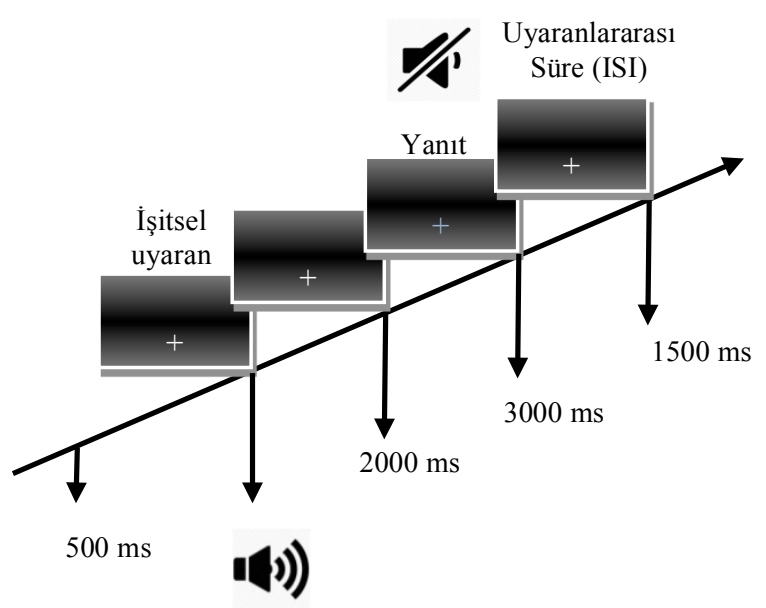

Şekil 4. İsitsel uyaran prosedürü

\section{2 ÇBU Yönteminin Süreç-Dışı (Davranışsal) Bulgulara Etkisi}

İşitsel uyaran setlerinin davranışsal verilerine ait istatistiksel analizler için parametrik olmayan dört yönlü Friedman S Testi kullanılmıştır. Bu aşamada başlangıçta deney koşulları (Dilbilgisel Koşul, Bürün Bozulması Koşulu, Sözdizim Bozulması Koşulu, Bürün-Sözdizim Bozulması Koşulu) arasındaki temel anlamlılık seviyeleri belirlenmiş, ardından da birbirine dilbilimsel açıdan yakınlık gösteren iki koşulun aynı dağılımsallık seviyesini taşıyıp taşımadığının belirlenmesi amacıyla iki yönlü Wilcoxon Testi uygulanmıştır. Aşağıda Tablo 
10'da İşitsel Uyaran Seti (1)'e, Tablo 11'de ise ÇBU Yöntemi ile oluşturulan İşitsel Uyaran Seti (2)'ye ilişkin davranışsal verilerin istatistiksel görünümleri sunulmaktadir.

Tablo 10. Issitsel Uyaran Seti (1)'e ilişkin davranışsal ortalamalar ve standart yanllş oranlarl

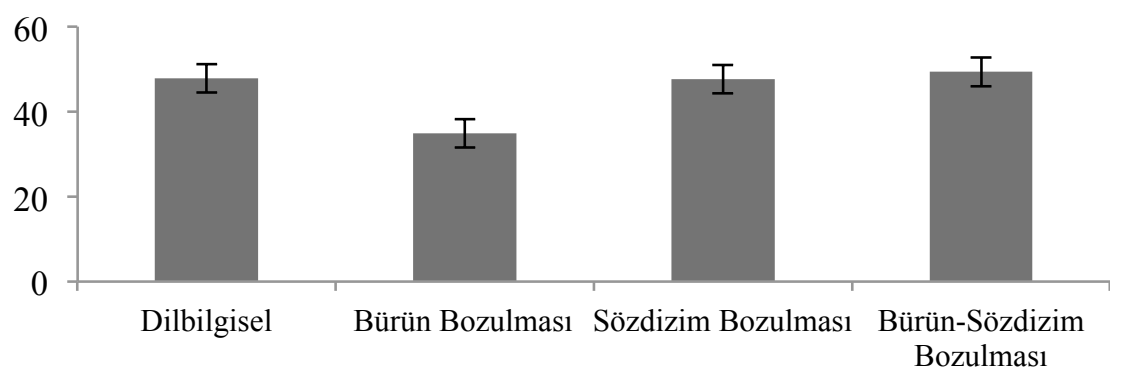

Tablo 10'da sunulan koşullar arasındaki anlamlılı̆̆ı gösteren Friedman S Testi sonuçlarına göre $\mathrm{X}^{2}(3)=30.283, \mathrm{p}<0.00$ düzeyinde tüm koşullar arasında yüksek oranda bir farklılık oluştuğu görülmektedir. Buna bağlı olarak, dilbilimsel açıdan bozulma görülmeyen ve sabit koşul (baseline condition) olarak görülen Dilbilgisel koşulun diğer koşullarla arasındaki dağılımsal farklılığını gösteren Wilcoxon Testi sonuçlarına göre şu şekilde bir anlamlılık düzeyi ortaya çıkmaktadır: Dilbilgisel Koşul $\times$ Bürün Bozulması Koşulu $(Z=3.152, p<0.05)$, Dilbilgisel Koşul $\times$ Sözdizim Bozulması Koşulu $(Z=0.794$, $\mathrm{p}>0.05)$, Dilbilgisel Koşul $\times$ Bürün-Sözdizim Bozulması Koşulu $(Z=2.239$, $\mathrm{p}<0.05$ ). Bununla birlikte, dört deney koşuluna ilişkin standart yanlış oranları ise şu şekildedir: Dilbilgisel Koşul (Ortalama=47.83, SD=2.89), Bürün Bozulması Koşulu (Ortalama=34.88, SD=17.67), Sözdizim Bozulması Koşulu (Ortalama=47.66, SD=1.94), Bürün-Sözdizim Bozulması Koşulu (Ortalama=49.33, SD=1.02). Ulaşılan davranışsal veri sonuçları incelendiğinde, deney koşulları arasında bütüncül açıdan yalnızca bürünsel bozulmayı gösteren Bürün Bozulması koşulunda belirgin bir farklılık oluştuğu, ancak diğer koşullar arasında dikkate değer bir anlamlı farklılık oluşmadı̆̆ı gözlemlenmektedir. 
Tablo 11. Isşitsel Uyaran Seti (2)'ye ilişkin davranışsal ortalamalar ve standart yanlış oranları

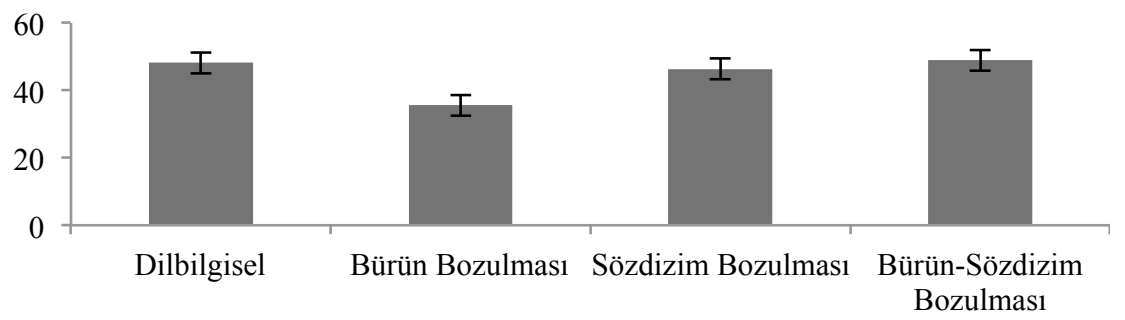

Tablo 11'de İşitsel Uyaran Seti (2)'ye ait bütün koşullar arasındaki istatistiksel sonuçlar Friedman S Testi çerçevesinde incelendiğinde, $X^{2}(3)=64.126, p<0.00$ düzeyinde yüksek oranda bir farkl1lık oluştuğu görülmektedir. $\mathrm{Bu}$ bulgu, koşulların kendi arasındaki dağılımsal düzeylerini ortaya koyan Wilcoxon Testi açısından deneyin temel koşulu olan Dilbilgisel Koşul'un diğer koşullar arasındaki bağıntısı çerçevesinde incelendiğinde ise ortaya şöyle bir anlamlılık düzeyi çıkmaktadır: Dilbilgisel Koşul $\times$ Bürün Bozulması Koşulu ( $Z=4.570$, $\mathrm{p}<0.05)$, Dilbilgisel Koşul $\times$ Sözdizim Bozulması Koşulu $(Z=2.719, p<0.05)$, Dilbilgisel Koşul $\times$ Bürün-Sözdizim Bozulması Koşulu $(Z=1.781, p>0.05)$. Tüm deney koşullarına ilişkin standart yanlış oranları ise şu şekildedir: Dilbilgisel Koşul (Ortalama=48.13, SD=2.04), Bürün Bozulması Koşulu (Ortalama=35.58, SD=15.02), Sözdizim Bozulması Koşulu (Ortalama=46.31, $\mathrm{SD}=2.01$ ), Bürün-Sözdizim Bozulması Koşulu (Ortalama = 48.93, SD=1.55). ÇBU yönteminin kullanıldığı bu EEG deneyinin davranışsal veri sonuçlarında, bürünsel bozulma diğer deney koşullarıyla karşılaştırıldığında, İşitsel Uyaran Seti (1)'e ait davranışsal sonuçlara karşın, daha düşük düzeyde anlamlılık oluşturduğu görülmektedir. Bu durum, dil sisteminin beyindeki işlemlenişini inceleyen araştırmalarda sıklıkla karşılaşılan bir durumu göstermektedir. Buna göre, bürünün çözümlenmesi diğer dilsel bozulmalara göre daha karmaşık bir süreç içerdiği için, bürünsel bozulma genellikle daha geç fark edilmektedir.

\section{3 ÇBU Yönteminin Süreç-İçi (EEG) Bulgulara Etkisi}

EEG deneylerinden elde edilen olaya ilişkin beyin potansiyelleri bulguları, özellikle bürün dizgesinin eylem-sonu konumunda bozulması sonucu temel etkisinin incelendiği belirli zaman pencerelerinde (400-600 ms, 500-800 ms ve 400-1200 ms) ÇBU yönteminin kullanılmasının önemini ortaya koymaktadır. Bu bağlamda ilk olarak, İşitsel Uyaran Seti (1) ile uygulanan Deney (1)'de dilbilgisel koşul ve bürün bozulması koşulu arasındaki 400-600 ms aralığında oluşması beklenen RAN Etkisinin, İşitsel Uyaran Seti (2) ile uygulanan Deney (2)'de açıkça gözlemlenebildiği görülmektedir. Deney (1)'de bürünsel 
bozulmanın eylem-sonu konumundaki elektrofizyolojik etkisini gösteren RAN Etkisi, Koşul $\times$ İlgi Alanı $\times$ Yarıüre etkileşiminde $[F(2,5)=.441, \mathrm{p}>0.05]$ düzeyinde bir anlamlılık taşımamaktadır. Benzer şekilde bürünsel bozulmaya ilişkin diğer alt istatistiksel bulgularda da Koşul $\times$ İlgi Alanı etkileşiminde $[F(1,2)=.449, \mathrm{p}>0.05]$ ve Koşul $\times$ Yarıüre etkileşiminde $[F(2,5)=.484, \mathrm{p}>0.05]$ açısından herhangi bir anlamlılığın oluşmadığı gözlemlenmiştir. Ancak ÇBU Yönteminin uygulandığı 2. İşitsel Uyaran Testinin kullandığını Deney (2)'ye ait sonuçlarda bürünsel bozulmanın beyindeki elektrofizyolojik etkisi açıkça gözlemlenmektedir. Deney (2)'de RAN Etkisi, Koşul $\times$ İlgi Alanı $\times$ Yarıüre etkileşiminde $[F(2,5)=5.288, \mathrm{p}=.017]$ düzeyinde anlamlılık içermektedir. Öte yandan, dilbilgisel koşul ve bürün bozulması koşulu arasındaki farklılığın incelendiği Koşul $\times$ İlgi Alanı etkileşiminde $[F(1,2)=12.912, \quad \mathrm{p}=.000]$ düzeyinde yüksek anlamlılık elde edilmiştir. Bu durum, aşağıda sunulan EEG topografilerinde de görülebilmektedir. Bununla birlikte, dilbilgisel koşul ve bürünsel koşul arasında 400-1200 ms zaman penceresinde Sol Arka Pozitivite Etkisi olarak Türkçede ilk defa görülen bürünün uzun süreli geç dönem etkisine İşitsel Uyaran Seti (1) ile uygulanan Deney (1)'de ulaşılamamış, ancak İşitsel Uyaran Seti (2) ile uygulanan Deney (2)'de bu potansiyel bürünsel bozulma içeren iki ayrı koşulda da belirgin bir anlamlılık oluşturmuştur. Buna göre, dilbilgisel koşul ve bürün bozulması koşulu arasında Koşul x İlgi Alanı x Yarıüre etkileşiminde $[F(2,5)=13.428, \quad \mathrm{p}=.000]$ düzeylerinde yüksek anlamlılık değerleri elde edilmiştir. $\mathrm{Bu}$ araştırmada ayrıntılı olarak söz edilmeyen, ancak Türkçede bürün dizgesinin beyindeki işlemlenişi süreci açısından özgün nitelikli olan Sol Arka Pozitivite Etkisi, eylem-sonu konumunda oluşan bürünsel bozulmanın beyindeki telafi etkisinin uzun dönemli bir potansiyele yayıldı̆̆ını göstermektedir.

Deney (1)


400-600 ms

Deney (2)

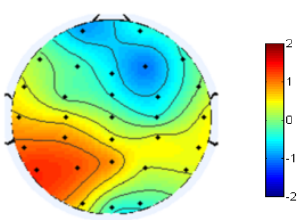

400-600 ms



400-1200 ms

Şekil 5. Eylem-sonu konumundaki bürünsel bozulmayı gösteren topografilerin Deney (1) ve Deney (2) arasindaki farklılıkları 
Dilbilgisel koşul ve sözdizim bozulması koşulu arasında işitsel uyaran setleri açısından oluşan farklılık incelendiğinde ise, işitsel uyaran setlerinin farklı bir yöntemle uygulanmasının olaya ilişkin potansiyel bulgularında belirgin bir farklılığa neden olmadığı gözlemlenmiştir. Buna göre, İşitsel Uyaran Seti (1) ile kurulan Deney (1)'e ait dilbilgisel koşul ve sözdizim koşul farklılığında Sol Ön Negativite (Left Anterior Negativity/LAN) Etkisi, Koşul $\times$ İlgi Alanı $\times$ Yarıüre etkileşiminde $[F(2,5)=.547, \mathrm{p}>0.05]$; Deney $(2)$ 'de ise Koşul $\times$ İlgi Alanı $\times$ Yarıküre etkileşiminde $[F(2,5)=.292, \mathrm{p}>0.05]$ düzeyinde anlamlılık farklılık bulgusu göstermemiştir. $\mathrm{Bu}$ durum, beklenildiği gibi, süreç-içi çözümleme sırasında sözdizimsel bozulmaların işitsel uyaranların sunulum farklılığından fazla etkilenmediğini göstermektedir ${ }^{8}$.

\section{Sonuç}

$\mathrm{Bu}$ araştırmada EEG tekniği kullanılarak, Türkçede eylem-sonu konumunda bürün-sözdizim etkileşimini inceleyen iki ayrı deneye ait işitsel uyaran setleri, temel sıklık (Hz) ve sesletim süreleri (ms) açısından karşılaştırılarak yorumlanmıştır. İşitsel Uyaran Seti (1)'de ÇBU yönteminin kullanılmadığı ve akustik önişlemlemeden geçirilmemiş işitsel uyaran seti, İşitsel Uyaran Seti (2)'de Türkçede ilk defa Bekâr (2016)'da sınanmış olan ve ÇBU yöntemiyle hazırlanan deney seti istatistiksel olarak yorumlanmıştır. Elde edilen bulgular, işitsel uyaranlar arasında hem temel sıklık değerleri hem de sesletim süresi değerleri açısından İşitsel Uyaran Seti (1)'deki verilerin, İşitsel Uyaran Seti (2)'deki verilere göre daha orantısız bir görünüm sergilediğini ortaya koymaktadır. KOŞUL [(Dilbilgisel Koşul, Bürün Bozulması Koşulu, Sözdizim Bozulması Koşulu, Bürün-Sözdizim Bozulması Koşulu)], KONUM [(tümcebaş1, eylem-öncesi, eylem, eylem-sonu)] ve DEĞİŞTİRGEN [(temel sılklık, sesletim süresi)] olmak üzere üç açıdan incelenen işitsel uyaranların, İşitsel Uyaran Seti (1)'de bürünsel bozulmaya ilişkin koşullar arasındaki anlaşılabilirlik düzeyini azalttığı göze çarpmaktadır. Bununla birlikte, İşitsel Uyaran Seti (1)'de eylem-öncesi konumlarına ait temel sıklık ve sesletim süresi değerlerinin istatistiksel açıdan İşitsel Uyaran Seti (2)'ye göre daha anlamsız biçimde dağıldığ 1 dikkat çekmektedir. ÇBU yönteminin en önemli noktasını ortaya koyan bu bulgu, katılımcıların sesbilimsel açıdan işitsel uyaranlar arasındaki farklılıkları anlamlandırabilmeleri açısından büyük önem taşımaktadır.

EEG deneylerinin karşılaştırılması sonucunda ulaşılan bulgular, İşitsel Uyaran Seti (1)'de işitsel uyaranı oluşturan söz öbeklerinin odaklama alanını inceleyen temel siklık değerlerinde dengesiz bir dağılım olduğunu ortaya

\footnotetext{
8 Türkçede eylem-sonu konumunda bürün-sözdizim etkileşimine ilişkin olaya ilişkin
} potansiyel bulguları hakkında daha ayrıntılı bilgi için bkz. Bekâr (2016). 
koymuştur. Ancak akustik önişlemlemeden geçirilerek kontrollü bir biçimde katılımcıya sunulan İşitsel Uyaran Seti (2)'de, işitsel uyaranları oluşturan söz öbeklerinin hem sesletim sürelerinde hem de temel sıklık değerlerinde yerinde bir dağılımsallık olduğu göze çarpmaktadır. Bu bulgu, olaya ilişkin beyin potansiyelleriyle çözümlenen süreç-içi EEG verilerine de yansımıştır. Bekâr (2016)'da İşitsel Uyaran Seti (1)'e ait EEG bulguları incelendiğinde, Bürünsel Bozulma koşulu ile Dilbilgisel koşulun karşılaştırılması sonucu, araştırmada hipotezlenen RAN Etkisi bulanık bir örüntü göstermiş ve istatistiksel olarak açıkça ortaya konamamıştır. Ancak, ÇBU yöntemiyle kurulan İşitsel Uyaran Seti (2)'ye ait olaya ilişkin potansiyel bulguları incelendiğinde, Türkçede eylem-sonu konumunda bürünsel bozulma sonucu RAN Etkisi temel etki analizlerinde açıkça gözlenmiş̧ir. Bununla birlikte, aynı uyaran setine ait olaya ilişkin potansiyel bulgularında Türkçede bürün bozulmasının telafi etkisini gösteren Sol Arka Pozitivite Etkisi de ortaya konmuştur. Ancak bu pozitivite etkisine ya da buna benzer bir başka EEG bulgusuna İşitsel Uyaran Seti (1)'de herhangi bir biçimde ulaşılamamıştır.

Öte yandan, süreç-dışı bir teknik olan davranışsal veri analizlerinde, işitsel uyaran setindeki akustik önişlemleme farklılığının eylem-sonu konumundaki bürünsel bozulma farkındalığını dikkate değer biçimde değiştirmediği dikkat çekmektedir. Bu bulgu, yalnızca motor hareketlerle verilen yanitları ölçen süreç-dışı verilerle, beyindeki elektrofizyolojik farklılığı ölçen süreç-içi EEG verileri arasında yorumlama açısından önemli bir ayrımın olduğunu da gösterir niteliktedir. $\mathrm{Bu}$ durumda, işitsel uyaran setlerindeki akustik önişlemleme farklılığının süreç-içi beyin görüntüleme teknikleri ile incelendiğinde daha hassas biçimde ortaya konulabildiği görülmektedir. $\mathrm{Bu}$ bulgu, süreç-dış1 ve süreç-içi tekniklerle uygulanan araştırmalara ilişkin sonuçların farkl1lık taşıyabileceğini, süreç-içi tekniklerin en küçük akustik değişimlerden bile etkilenebileceğini ve bu akustik farklılıkların sesbilimsel ve nörodilbilimsel sonuçlara etki edebileceğini açıkça göstermektedir.

Yukarıda sunulan vargılar, Türkçede işitsel teknik kullanılarak oluşturulacak işitsel uyaran setlerinin ÇBU yöntemi gibi akustik önişlemleme yöntemleriyle oluşturulmasının gerekliliğini ortaya koymaktadır. Bu akustik karşılaştırma araştırması, Türkçe üzerine ileride yapılması hedeflenen işitsel tekniğe dayalı uyaran setlerinin hazırlanması sürecinde akustik araçların kullanımının önemini vurgulamaktadır. Temel sıklık ve sesletim süresi gibi temel akustik araçların yerinde kullanımı sonucu, katılımcıların işitsel uyaranlarda yalnızca çözümlemesi beklenen dilsel alanlara odaklanmaları ve deneyin akışını bozan diğer dilsel alanlardan uzaklaşmaları sağlanmaktadır. Uluslararası alanyazında yukarıdaki bölümlerde de söz edildiği gibi pek çok araştırmada kullanılan bu akustik çözümleme yönteminin, Türkçe üzerinde uygulanan sesbilim temelli disiplinlerarası araştırmalarda kullanımının çoğalması beklenmektedir. 


\section{Kaynaklar}

Astésano, C., Besson, M. ve Alter, K. (2004). Brain potentials during semantic and prosodic processing in French. Cognitive Brain Research (18): 172-184.

Beckman, M.E. (1996). The parsing of prosody. Language and Cognitive Processes (11): $17-67$.

Bekâr, İ.P. (2016). Türkçede Eylem-Sonu Konumunda Bürün-Sözdizim Etkileşimi Üzerine Elektrofizyolojik Bir İnceleme. Ankara Üniversitesi. Sosyal Bilimler Enstitüsü. Yayınlanmamış Doktora Tezi.

Boersma, P. (1993). 'Accurate short-term analysis of the fundamental frequency and the harmonics-to-noise ratio of a sampled sound'. IFA Proceedings 17, 1993. s. 97-110.

Boersma, P. ve Weenink, D. (2010). 'PRAAT: doing phonetics by computer (Versiyon 5.2) [bilgisayar program1],' www.praat.org.

Bögels, S. (2007). The interplay between prosody and syntax in sentence processing: Two ERP-studies. Nijmegen CNS (2):1.

Clark J., Yallop, C. ve Fletcher, J. (2007). Introduction to Phonetics and Phonology. Oxford: Blackwell.

Crystal, D. (1969). Prosodic Systems and Intonation in English. Cambridge University Press. 1. Bask1.

Crystal, D. (1980). A Dictionary of Linguistics and Phonetics. Wiley Yayınları.

Eckstein, C. ve Friederici, A.D. (2005). Late interaction of syntactic and prosodic processes in sentence comprehension as revealed by ERPs. Cognitive Brain Research (25): 130-143.

Eckstein, C. ve Friederici, A.D. (2006). Its early: event-related potential evidence for initial interaction of syntax and prosody in speech comprehension. Journal of Cognitive Neuroscience (18): 1696-1711.

Erguvanl1, E. (1984). The function of word order in Turkish grammar. Berkeley: Kaliforniya Üniversitesi Yayını.

Fant, G. (1960). Acoustic Theory of Speech Production. Mounton \& Co, The Hague, Hollanda.

Friederici, A.D. (2002). Towards a neural basis of auditory sentence processing. Trends in Cognitive Sciences (6): 78-84.

Göksel, A. (1998). Linearity, focus and the postverbal position in Turkish. İçinde: L. Johanson (Yay.), The Mainz Meeting Proceedings of the Seventh International Conference on Turkish Linguistics (s. 85-106). Wiesbaden, Harrosowitz, Verlag.

Hagoort, P., Brown, C. M., ve Groothusen, J. (1993). The syntactic positive shift (SPS) as an ERP measure of syntactic processing. Language and Cognitive Processes (8): 439-483.

Hwang, H. ve Steinhauer, K. (2011). Phrase length matters: the interplay between implicit prosody and syntax in Korean 'garden path' sentences. Journal of Cognitive Neuroscience (23): 3555-3575.

Kent, R.D. ve Read, C. (2002). Acoustic Analysis of Speech. Thomson Learning. İkinci Bask1.

Kerkhofs, R., Vonk, W., Schriefers, H. ve Chw1lla, D. J. (2007). Discourse, syntax, and prosody: the brain reveals an immediate interaction. Journal of Cognitive Neuroscience (19): 1421-1434. 
Koelsch, S. (2009). Music-syntactic processing and auditory memory: Similarities and differences between ERAN and MMN. Psychophysiology (46): 179-190.

Koelsch, S., Gunter, T., Friederici, A.D. ve Schröger, E. (2000). Brain indices of music processing: "nonmusicians" are musical. Journal of Cognitive Neuroscience 12 (3): $520-41$.

Koelsch, S., Gunter, T., Wittfoth, M. ve Sammler, D. (2005). Interaction between syntax processing in language and in music: an ERP study. Journal of Cognitive Neuroscience 17 (3): 1565-77.

Ladefoged, P. (2006). A Course in Phonetics. Thomson/Wadsworth Yayınları. Beşinci Bask1.

Li, W. ve Yang, Y. (2009). Perception of prosodic hierarchical boundaries in Mandarin Chinese sentences. Neuroscience (158): 1416-1425.

Magne, C., Astésano, C., Aramaki, M., Ystad, S., Kron-land-martinet, R. ve Besson, M. (2007). Influence of syllabic lengthening on semantic processing in spoken French: Behavioural and electrophysiological evidence. Cerebral Cortex 17(11): 2659-2668.

Männel, C. ve Friederici, A.D. (2009). Pauses and Intonational Phrasing: ERP Studies in 5-month-old German Infants and Adults. Journal of Cognitive Neuroscience 21(10): 1988-2006.

Osterhout, L. ve Holcomb, P. (1992). Event-related potentials and syntactic anomaly: Evidence of anomaly detection during the perception of continuous speech. Submitted manuscript

Pannekamp, A., Toepel, U., Alter, K., Hahne, A. ve Friederici, A.D. (2005). Prosodydriven sentence processing: an event-related brain potential study. Journal of Cognitive Neuroscience (17): 407-421.

Patel, A.D., Gibson, E., Ratner, J., Besson, M. ve Holcomb, P.J. (1998). Processing syntactic relations in language and music: an event-related potential study. Journal of Cognitive Neuroscience 10 (6): 717-33.

Steinberg, J., Truckenbrodt, H. ve Jacobsen, T. (2012). The role of stimulus crosssplicing in an event-related potentials study. Misleading formant transitions hinder automatic phonological processing. Journal of Acoustical Society of America, 131 (4): 3120-3140.

Steinhauer, K. ve Friederici, A.D. (2001). Prosodic Boundaries, Comma Rules, and Brain Responses: The Closure Positive Shift in ERPs as a Universal Marker for Prosodic Phrasing in Listeners and Readers. Journal of Psycholinguistic Research 30 (3): 267-95.

Steinhauer, K., Alter, K. ve Friederici, A.D. (1999). Brain potentials indicate immediate use of prosodic cues in natural speech processing. Nature America (2): 191-196.

Stevens, K. (2000). Acoustic Phonetics. The MIT Press. Birinci Bask1.

Wolff, S., Schlesewsky, M., Hirotani, M. ve Bornkessel-Schlesewsky, I. (2008). The neural mechanisms of word order processing revisited: electrophysiological evidence from Japanese. Brain and Language (107): 133-157. 